\title{
How is the process of setting micronutrients recommendations reflected in nutrition policies in Poland? The case study of folate
}

\author{
Ewa Sicińska', Marta Jeruszka-Bielak', Wojciech Roszkowski', Anna Brzozowska', \\ Mirosław Jarosz ${ }^{2}$, Monique M. Raats ${ }^{3}$ \\ ${ }^{1}$ Department of Human Nutrition, Warsaw University of Life Sciences-SGGW, Warsaw, Poland \\ ${ }^{2}$ The National Food and Nutrition Institute, Warsaw, Poland \\ ${ }^{3}$ Food Consumer Behaviour and Health Research Centre, School of Psychology, University of Surrey, Guildford, Surrey, \\ United Kingdom
}

Sicińska E, Jeruszka-Bielak M, Roszkowski W, Brzozowska A, Jarosz M, Raats MM. How is the process of setting micronutrients recommendations reflected in nutrition policies in Poland? The case study of folate. Ann Agric Environ Med. 2018; 25(1): 82-86. doi: 10.5604/12321966.1230670

\begin{abstract}
Introduction and objective. Ensuring the adequate intake of micronutrients by populations is an important aspect of public health. This study aims to elucidate the process of setting nutrition recommendations and the development of subsequent policies associated with micronutrients in Poland by using the case study of folate.

Materials and method. The study was based on 13 interviews conducted between October 2010 - February 2011 , and desk research comprising a review of the associated scientific literature and relevant documents, such as scientific opinions and reports of the meetings of scientific committees. The interviews were conducted within the EURRECA (EURopean micronutrient RECommendations Aligned) Network of Excellence in the frame of the European Union's 6th Framework Programme.

Results. Since 1997, the Experts Group of the Ministry of Health recommended that all women of childbearing age should consume folic acid as a supplement to prevent neural tube defects in their offspring. The fortification of foodstuffs with folic acid is not obligatory. This study describes the revision of the folate nutrient recommendation and the process by which strategies to increase the intake of this vitamin by the Polish population were identified. The institution responsible for the choice and implementation of folate policy is the Ministry of Health and the National Food and Nutrition Institute is responsible for setting/updating the nutrient recommendations.

Conclusions. The current Polish nutrition recommendations for folate are consistent with the levels set by most other countries. The constant improvement of nutritional knowledge on folate among consumers, especially young women, is necessary.
\end{abstract}

\section{Key words}

micronutrients, nutrition policy, public health, folate

\section{INTRODUCTION}

Ensuring an adequate intake of micronutrients by populations is an important aspect of public health, and requires the implementation of an appropriate national nutrition policy. The nutrition policy makers and scientific advisory bodies should regularly update the micronutrient recommendations to reflect new scientific evidence [1].

The EURRECA Network of Excellence has been working towards the development of aligned micronutrients recommendations across Europe. Folate, vitamin D and iodine were selected from the ten priority micronutrients [1] for the purpose of reviewing their requirements. These three micronutrients provided contrasting case studies in terms of their historical context, as well as current policies or recommendations in different European countries (Czech Republic, United Kingdom, Italy, Netherlands, Nordic countries, Poland, and Spain).

\footnotetext{
Address for correspondence: Ewa Sicińska, Department of Human Nutrition, Warsaw University of Life Sciences-SGGW, Warsaw, Poland

E-mail: ewa_sicinska@sggw.pl

Received: 10 March 2014; accepted: 20 January 2015; first published on December, 2016
}

It is estimated that the folate intake in some subpopulations in Poland is insufficient. According to the studies published in 2000-2010, the average intake of this water-soluble B-vitamin among Polish adults (18 - 96-years-old) was within the range $110-352 \mu \mathrm{g} /$ person/day from dietary sources; the fortified products and dietary supplements were rarely measured in these studies [2]. The average dietary folate intake among pregnant women was low - $160 \mu \mathrm{g} /$ person/day [3].

Prolonged folate deficiency is associated with risk of many diseases, such as megaloblastic anaemia, the occurrences of congenital malformations in offspring, degenerative diseases of the nervous system, cardiovascular diseases, depressive disorder and some types of cancers. The impact of supplementation on the decrease of neural tube defects (NTDs) is well documented [4]. In Poland, the prevalence of NTDs in 2005-2006 (6.7 per 10,000 live births) was much higher than in most European countries (average 2.6 per 10,000 live births) [5].

\section{OBJECTIVE}

The objective of this study was to elucidate in detail the process of setting nutrition recommendations, and the development 
of subsequent policies associated with micronutrients in Poland. This paper presents the case study of folate.

\section{MATERIALS AND METHOD}

The case study used in-depth desk research and interview data concerning the investigation of the decision-making processes for the request to the body, the process of developing and implementing relevant micronutrient policies, and the use of recommendations. Particular attention is paid to the setting-up of a committee of experts (e.g. expert committee/scientific advisory board, terms of reference. What is their remit? Who is on these committees?) and identifying the most appropriate policy option(s) (e.g. use of recommendations in policy selection, the policy decisionmaking process) as elements of EURRECA's approach for estimating micronutrient requirements [6].

Desk research. Different strategies were used in order to collect all the relevant information for the desk research to minimise the risk of omitting any core publication(s). First, information and publications were sought for on official websites, especially the main scientific societies and industrial organisations concerned with nutrition. Secondly, fruitful sources of information were the expert committees, that made access possible to relevant documents, e.g. reports, opinions, minutes of meetings, scientific publications, administrative and consultation documents. Finally, all the potentially important documents was the reference hand search within scientific papers and books were gathered.

Interviews. In October-February 2010-2011, two series of semi-structured interviews were conducted with Polish decision-makers and relevant scientific institutions in the field of nutrition and public health. Respondents represented the scientific advisory bodies, a non-governmental institution, industry and administration representatives. During the first round of nine interviews, information was collected on the decision-making process of developing micronutrients policies, with special focus on folate, vitamin $\mathrm{D}$ and iodine.The second round of four interviews gleaned information from nutrition policy makers on the process of requesting, setting and communicating micronutrients recommendations to the policy making area. The same questionnaires were used in all participating countries.

\section{RESULTS}

In Poland, the first nutritional recommendations for folate were set in 1959 by the expert of the Chair of Nutrition at the National Institute of Hygiene (PZH). Since the institutional transformation in 1963, the newly-created National Food and Nutrition Institute (NFNI) has been the body responsible for setting/updating nutritional recommendations [7]. In 2008, the NFNI set the most recent revision of folate recommendations [8] which remained unchanged after subsequent amendments in 2012 [9].

Previous folate recommendations in the form of Recommended Dietary Allowances (RDA) for adults were $220-320 \mu \mathrm{g} /$ person/day for various age and gender groups at different levels of physical activity, and 400-480 during pregnancy and lactation, respectively [10]. According to the 2008 recommendation, the level of the RDA was increased to $400 \mu \mathrm{g} /$ person/day for adults, $600 \mu \mathrm{g} /$ person/day for pregnant women, and remained almost unchanged for lactating women at $500 \mu \mathrm{g} /$ person/day. Taking into account the bioavailability from different sources of folate, i.e. natural food, fortified food and dietary supplements, updated folate recommendations are expressed in dietary folate equivalents (DFE) $[8,9]$.

In 1997, the Experts Group of the Ministry of Health recommended that all women of childbearing age should consume $0.4 \mathrm{mg} / \mathrm{day}$ of folic acid as a supplement, and should not exceed $1 \mathrm{mg}$ of folic acid daily. Women who have already had a neural tube defects affected child should take $4 \mathrm{mg}$ of folic acid daily, and should also have the opportunity to have genetic counselling before the next pregnancy [11]. Also since 1997, the National Prevention Programme of Neural Tube Defects has been conducted by the Department of Epidemiology of the National Institute of Mother and Child in Warsaw. The aim of the programme is to encourage women of childbearing age to use folic acid supplements and fortified foods, which may be achieved by education campaigns (TV, radio, press), personal advice (in clinics, hospitals, work place, schools), and training courses for health professionals. A diet rich in folate is also recommended. The folic acid supplementation should be started at least four weeks before planned conception and should be continued during the first trimester of pregnancy [12]. The institution responsible for the choice, development and implementation of folate policy is the Ministry of Health. Monitoring of folate intake/ supplementation in selected population groups is conducted by the NFNI and other institutes; however, no information on the monitoring at national level could be retrieved.

In Poland, the fortification of particular foodstuffs with folic acid is not obligatory. The first document to regulate the amount of vitamins and minerals added to foods was the Regulation of the Ministry of Health on the fortification of foods from 2002. According to current regulation, different food groups, excluding unprocessed foodstuffs and beverages containing more than $1.2 \%$ by volume of alcohol, can be fortified with pteroiloglutamine acid or L-methylofolate-Ca. The permissible doses per $100 \mathrm{~g}$ or $100 \mathrm{ml}$ or per one portion of product are $15-100 \%$ of the nutrient reference values for nutrition labelling (NRVs), i.e. $200 \mu \mathrm{g}$ [13].

Revision/development of nutrition recommendations. The Group of Experts from the NFNI was involved in the process of the revision of nutrition recommendations in 2006-2008. The NFNI is a research institute linked to Ministry of Health, but works independently. It is composed of employees with medical training and broad competences in nutrition research, clinical nutrition and dietetics. Planning, organizing and conducting scientific research in the area of nutrition recommendations and dietary guidelines are the statutory priority tasks of the NFNI [7].

The above-mentioned group of experts consists of 26 employees of this Institute, many of whom have been engaged in this subject for decades and are the authors or co-authors of numerous publications in this field. The team is supervised by the Director of Institute [8]. Proposals for recommendations were presented and discussed during internal meetings at the Institute, as well as with external experts during the Scientific Advisory Conference. 
The revision of nutrition recommendations was required because the previous Polish recommendations were established in 1994 [10] and were lower than in other countries, e.g. USA and Canada. Also, the unfavourable health status of the Polish population, e.g. high incidence of NTDs and elevated blood homocysteine in elderly people, needed to be improved. The most important areas of discussion during the process of setting recommendations were: to clearly define and agree on Polish terms for different recommendations the Estimated Average Requirement (EAR), Recommended Dietary Allowances (RDA), and Adequate Intake (AI), to describe in detail equivalents for folate, underline the specificity of the Tolerable Upper Intake Level for the form of the vitamin (only for the synthetic form). The new and final folate recommendations were based on the US and Canadian, as well as $\mathrm{FAO} / \mathrm{WHO}$ recommendations, which considered the erythrocyte reserves and optimal homocysteine blood concentration as the main evidence $[4,14]$.

Insights from the interviews to contextualise the process of updating the recommendations on folate are presented in Table 1.

Reviewing the process of establishing policy - mandatory/ voluntary food fortification. By 2005, several countries already had food mandatory fortification with folic acid (e.g. USA, Canada); therefore, the Group of Experts from Polish Society for Atherosclerosis suggested obligatory fortification of flour with folic acid. They appealed for the need to increase folate intake, especially among young women and the elderly, through higher daily consumption of vegetables and fruit, as well as fortified foods which would have a beneficial effect on the health of Polish people. They underlined the necessity for countrywide flour fortification with folic acid [15]. In 2006, the Minister of Health appointed the Scientific Advisory Committee (SAC) to consider the implications of obligatory flour fortification with folic acid. The Committee's task was to review the literature, to characterise the groups of special considerations, analyse the risks and benefits, and costs of obligatory food fortification with folic acid. There were 18 experts sitting on the SAC board, including the director of the Health Department at the Ministry of Health as chairman, and experts from the National Food and Nutrition Institute, the Ministry of Health, National Research Institute of Mother and Child, Warsaw University of Life Sciences (WULS-SGGW), the Medical University of Warsaw, National Consultants in Paediatric, Cardiology, Gynaecology, and Diabetology. The team of experts was to be dissolved after their tasks had been completed [16].

During meetings, the SAC discussed several issues: the number of women of childbearing age who take folic acid supplements, the women's knowledge and effectiveness of education campaigns, health status of subpopulations, sources of folate in a daily diet, nutritional habits of different consumer groups, costs and monitoring of mandatory/ voluntary fortification, consistently increasing number of fortified foods and dietary supplements on the market, and the risk of overdosing.

The Committee analysed the risks and benefits of obligatory food fortification with folic acid, but the evidence at that time was insufficient to make such a decision. It could involve the risk of folic acid overload among some populations. The Committee recommended carrying on with the educational programmes focused on increasing the intake of foods rich
Table 1. Insights from the interviews to contextualise the updating of recommendations on folate

\begin{tabular}{|c|c|}
\hline $\begin{array}{l}\text { Initiative } \\
\text { of revision/ } \\
\text { development }\end{array}$ & $\begin{array}{l}\text { 'The initiative came from director of the National Food and Nutrition } \\
\text { Institute, who led the National Cardiovascular Disease Prevention } \\
\text { and Treatment Programme (2006-2008) and in this programme the } \\
\text { novelisation of recommendations was included. Besides, there were } \\
\text { published new recommendation in many countries, especially in the } \\
\text { USA and Canada, and in some EU countries.' } \\
\text { 'Concerning the folate: firstly, there are quite huge discrepancies } \\
\text { between Polish recommendations and those in other countries. } \\
\text { Secondly, elevated blood homocysteine level and a quite big } \\
\text { percentage of NTDs in the Polish population. Also, the health policy: } \\
\text { how to improve the situation(...).' }\end{array}$ \\
\hline $\begin{array}{l}\text { Processes of } \\
\text { setting }\end{array}$ & $\begin{array}{l}\text { 'Proposals for recommendations were presented and discussed } \\
\text { during meetings of the Group of Experts from the Institute; they } \\
\text { were also reviewed during a consultative conference (National Food } \\
\text { and Nutrition Institute, 29 December 2006), which was attended by } \\
\text { experts from other scientific centres, including Warsaw University of } \\
\text { Life Sciences (former Warsaw Agriculture University), The Children's } \\
\text { Memorial Health Institute, Medical University of Warsaw, University } \\
\text { of Warmia and Mazury, University of Life Sciences and University } \\
\text { of Medical Sciences in Poznań. An additional evaluation of the new } \\
\text { recommendations was made before publication.' } \\
\text { 'Many discussions in the expert group were connected with the } \\
\text { notions/terminology of new recommendations, which were very } \\
\text { different from those previously used. There was a need for precise } \\
\text { meanings of EAR, RDA and Al. We also discussed the UL for vitamins } \\
\text { and minerals, which were inserted for the first time into the Polish } \\
\text { Recommendations. An important issue was to establish Polish } \\
\text { names for those levels (...). Besides, we debated about the range } \\
\text { of age for subgroups, especially in children, teenagers and elderly } \\
\text { people. (...) In the case of vitamins, uncertainties were connected } \\
\text { mostly with folate, especially the name, equivalents, underlining } \\
\text { that UL is only for folic acid (...). The Polish recommendations were } \\
\text { based on the experts' experiences from other countries. The values } \\
\text { of recommendations are in accordance with those given by FAO/ } \\
\text { WHO,USA and Canada, and are close to new recommendations in } \\
\text { Germany, Austria and Switzerland, as well as in Australia and New } \\
\text { Zealand.' }\end{array}$ \\
\hline $\begin{array}{l}\text { Usage/ } \\
\text { application }\end{array}$ & $\begin{array}{l}\text { 'In cooperation with the Ministry of Health, nutrition } \\
\text { recommendations were sent to appropriate centres related to the } \\
\text { Ministry. They were also used as a tool in some tasks of the POL- } \\
\text { HEALTH programme. At the same time, new recommendations } \\
\text { for children and adolescents were developed. In 2009, the } \\
\text { recommendations for children, adolescents and adults were } \\
\text { presented graphically, in the form of a pyramid, with suitable } \\
\text { comments. Nutrition recommendations were also included in } \\
\text { educational materials for dieticians.' } \\
\text { 'In setting nutrition recommendations in Poland, it would be helpful } \\
\text { to use the results of continuous monitoring of nutritional status and } \\
\text { nutrient intake, the management of which is planned in the coming } \\
\text { years.' }\end{array}$ \\
\hline
\end{tabular}

in folate, targeted at the general population and especially at groups at risk, i.e. adolescents and women of childbearing age. Besides, the SAC stated that there was a possibility to increase folic acid intake by consuming various voluntary fortified products and dietary supplements which allow the consumers to make their own choice. The final report and recommendations of SAC [17] became the official decision of the Ministry of Health.

Insights from the interviews to contextualise the development of policies about folate are presented in Table 2.

\section{DISCUSSION}

In nutrition policy, legislative options are usually only considered if all other options are deemed unsuitable, and regarding micronutrients, only a few EU countries have opted 
Table 2. Insights from the interviews to contextualise the policies on folate

\begin{tabular}{ll}
\hline Initiative & 'The process originated as a proposal from a physician (professor) \\
of revision/ & - a follower of mandatory fortification. Based on this proposal, the \\
development & Food and Nutrition Institute, among others, and appointed the \\
& group of experts to examine this issue in detail.' \\
'(...) Health outcomes were taken into account, outcomes from \\
other countries (with obligatory fortification) which suggested that \\
neural tube defects are fewer; however, the evidence for lowering \\
homocysteine concentrations was not so strong. Scientific evidence, \\
mainly from Western Europe and the USA, was analysed and the \\
results suggested that the excessive intake of folic acid by people \\
with early stages of colon cancer is not good for health. (...) We also \\
analysed the sources of folate in a daily diet; it appeared that people \\
who do not eat bread consume lower amount of this vitamin than \\
other people, which means that for this specific population fortifying \\
bread would be of no use since those people do not eat any bread \\
whatsoever.' \\
'(..) we took into account the perception of the consumer when \\
he sees that a product is fortified with folate. Consumers do not \\
know what folate is, and it seems to them to be a food preservative. \\
For example, this was a constraint in the campaign led by one of \\
the chain stores when it provided information that its bread was \\
fortified with folate.' \\
'The costs of obligatory fortification are quite low; however, the costs \\
of control procedures are high.' \\
'(...) voluntary fortification of foods with folate was accepted, and \\
we support the food industry divisions that are willing to do so.' \\
'(..) we observe the consequences of neural tube defects. In the \\
whole country we - The Children's Memorial Health Institute \\
together with the National Research Institute of Mother and \\
Child - carry out trainings for physicians (...) which include the \\
recommendation for women planning pregnancy to use folic acid \\
on a regular basis.' \\
application
\end{tabular}

for mandatory fortification, e.g. salt iodization. Voluntary fortification is more widely considered, but in countries such as Sweden or Norway even this is rarely acceptable [18].

In 2006, there were approximately 200 supplements and foods fortified with folic acid on the Polish market [17], while it is currently estimated to have increased to $550[19,20]$. In detail, in 2011 there were over 330 dietary supplements with folic acid, and over a half of them contained 200$400 \mu \mathrm{g} /$ dose [19]. In 2012, on the Warsaw market there were nearly 230 foodstuffs fortified with folic acid from various food categories, i.e. cereal products (43\%), while juices and non-alcoholic beverages (24\%) were the largest group [20]. The study conducted in 2010-2011 showed that products fortified with this vitamin were used by $89 \%$ of university students; however, about $25 \%$ of them were unaware that they were consuming fortified products [21].

Despite the education campaigns in 2006 , over $70 \%$ of young women were not able to define what 'folic acid' was, most respondents did not know the recommended daily dose of the vitamin, and did not adhere to the recommended supplementation advice [22]. In 2009, 22\% of women of childbearing age were familiar with the preliminary neural tube defects prevention programme. Only $1 / 5$ th of the respondents were familiar with and bought folic acid-fortified food products. About $76 \%$ of the respondents knew the optimum time to start supplementation in order to prevent neural tube defects, i.e. at least one month before conception. Every second respondent (54\%) knew that a $0.4 \mathrm{mg}$ tablet was the recommended daily dose. The knowledge of women of childbearing age was poor [23]. The actions undertaken to disseminate information about prevention of neural tube defects among women in 2001-2010 at the national and local levels are assessed to be ineffective in the Lower Silesian region, and need urgent verification [24]. In Poland, according to the studies published in 2000-2010, only about $18-25 \%$ of young, non-pregnant women declared taking folic acid supplements [2].

The necessity for improving the health of women and newborn, as well as health education to prevent NTDs, were included in the aims of the 2009-2013 National Plan for Diagnosis and Treatment of NTDs, published by the Ministry of Health [25]. The financial constraints of the Polish health system may influence the effective implementation of the above-mentioned goal on a national scale.

\section{CONCLUSIONS}

1. The levels of Polish nutrition recommendations for folate established in 2008 and maintained in 2012 are consistent with the levels set in most other countries.The monitoring of micronutrients intake and nutritional status at the national level would be very useful in the process of updating the nutritional recommendations in Poland.

2. Constant improvement of nutritional knowledge about folate among consumers, especially among young women to prevent neural tube defects in their offspring, is desirable. Currently, the number of dietary supplements and fortified foods with folic acid on the market appears to be quite large; therefore, the consumers have the possibility to choose such products to increase the intake of this vitamin.

\section{Acknowledgements}

The authors would like to thank all interviewees, who agreed to participate in our study. The work herein has been carried out within the EURRECA Network of Excellence (http:// www.eurreca.org), financially supported by Ministry of Science and Higher Education, grant Nr 520/6.PR UE/2008/7 (12 Feb 2008) and by the Commission of the European Communities, Specific Research Technology and Development (RTD) Programme Quality of Life and Management of Living Resources within the sixth framework programme, contract no. 036196 . The views expressed by the authors do not necessarily reflect the Commission's views or its future policy in this area.

The contributions of authors were as follows: ES, MJB and WR carried out data collection, analysis and desk research. ES, MJB, WR, AB and MJ were responsible for the Polish study concept. MMR supervised the study design, data collection and associated tasks within the EURRECA project. ES drafted and wrote the manuscript, and all authors were involved in manuscript revisions.

\section{REFERENCES}

1. Cavelaars AE, Doets EL, Dhonukshe-Rutten RA, Hermoso M, Fairweather-Tait SJ, Koletzko B, et al. Prioritizing micronutrients for the purpose of reviewing their requirements: a protocol developed by EURRECA. Eur J ClinNutr. 2010; 64(Suppl 2): S19-30.

2. Sicińska E, Wyka J. Folate intake in Poland on the basis of literature from the last ten years (2000-2010). Rocz Panstw Zakl Hig. 2011; 62(3): 247-256 (in Polish).

3. Bojar I, Owoc A, Humeniuk E, Wierzba W, Fronczak A. Inappropriate consumption of vitamins and minerals by pregnant women in Poland. Ann Agric Environ Med. 2012; 19(2): 263-266. 
4. Dietary reference intakes for thiamine, riboflavin, niacin, vitamin $\mathrm{B}_{6}$, folate, vitamin $B_{1}$, panthotenic acid, biotin and choline. Food and Nutrition Board, Institute of Medicine, Natl. Acad. Press, Washington DC 2000.

5. Latos-Bieleńska A, Materna-Kiryluk A. Wrodzone Wady Rozwojowe w Polsce w latach 2005-2006. Dane z Polskiego Rejestru Wrodzonych Wad Rozwojowych (Polish Registry of CongenitalMalformations) Ośrodek Wydawnictw Naukowych, Poznań, 2010. p.11-14. http://www. rejestrwad.pl/ (access: 2013.12.16) (in Polish).

6. Matthys C, van 't Veer P, de Groot L, Hooper L, Cavelaars AEJM, Collings R et al. EURRECA's Approach for Estimating Micronutrient Requirements. Int J VitamNutr Res. 2011; 81(4): 256-263.

7. Statut Instytutu Żywnościi Żywienia (Statute of the National Food and Nutrition Institute) http://www.izz.waw.pl/images/stories/PDF/ statut\%202011.pdf (access: 2013.12.16) (in Polish).

8. Jarosz M, Bułhak-Jachymczyk (eds.): Normy żywienia człowieka. Podstawy prewencji otyłości i chorób niezakaźnych (Polish Dietary Reference Intakes). PZWL, Warszawa 2008 (in Polish)

9. Jarosz M (ed.): Normy żywienia dla populacji polskiej - nowelizacja (Polish Dietary Reference Intakes - revision) IŻ̇̇, 2012. http://mail.izz. waw.pl/ it/NORMY/NormyZywieniaNowelizacjaIZZ2012.pdf (access: 2013.12.16) (in Polish).

10. Ziemlański Ś, Bułhak-Jachymczyk B, Budzyńska-Topołowska J, Paczenko-Kresowska B, Wartanowicz H. Recommended dietary allowances for Polish population (energy, protein, fat, vitamins and minerals) Żyw Człow Metab. 1994; 21(4): 303-338 (in Polish).

11. Stanowisko Zespołu Ekspertów Ministerstwa Zdrowia i Opieki Społecznej w sprawie zapobiegania wadom wrodzonym cewy nerwowej u potomstwa poprzez stosowanie kwasu foliowego (The standpoint of the Experts Group of the Ministry of Health and Human Welfare regarding prevention of inbred defects of neural tube in children using folic acid). Żyw Człow Metab. 1997; 24(1): 91-93 (in Polish).

12. Instytut Matki i Dziecka: Program pierwotnej profilaktyki wad cewy nerwowej (National Research Institute of Mother and Child: Primary prevention program of neural tube defects). http://www.imid.med.pl (access: 2013.12.16) (in Polish).

13. Rozporządzenie Ministra Zdrowia z dnia 16 września 2010 r. w sprawie substancji wzbogacających dodawanych do żywności (Regulation of the Ministry of Health on fortificants to foods, 16.09.2010) (in Polish)

14. Vitamin and Mineral requirements in human nutrition. WHO and FAO, Rome 2004.

15. Naruszewicz M, Członkowska A, Gaciong Z, Opolski G. Stanowisko Grupy Ekspertów w sprawie wzbogacania mąki kwasem foliowym (The standpoint of the Experts Group regarding on strategy to flour fortification with folic acid). Czynniki Ryzyka 2005; 1-2(45-46): 4 (in Polish).

16. Zarządzenie Ministra Zdrowia z dnia 25 kwietnia 2006 r. w sprawie powołania Zespołu do spraw opracowania strategii działań na rzecz suplementacji mąki kwasem foliowym, Dz.Urz.MZ.06.07.26 (Regulation of Ministry of Health appointed Scientific Advisory Committee on 25 April 2006 on strategy to flour fortification with folic acid. Off J Ministry Health 06.07.26. Dz U M Z 06.07.26) (in Polish).

17. Raport końcowy i rekomendacje Zespołu ds. Opracowania strategii działań na rzecz suplementacji mąki kwasem foliowym powołany dn. 2006.04.25 (Final report and recommendations: Scientific Advisory Committee on Strategy to Flour Fortification - set up in 2006.04.25) (unpublished data, in Polish).

18. Timotijevic L, Brown KA, Lähteenmäki L, de Wit L, Sonne AM, Ruprich J, Řehůřková I, Jeruszka-Bielak M, Sicińska E, Brito García N, Guzzon A, Jensen BB, Shepherd R, Barnett J, Raats MM. EURRECA - A Framework for Considering Evidence in Public Health Nutrition Policy. Crit Rev Food Sci Nutr. 2013; 53(10): 1124-1134.

19. Sicińska E, Wasik M. Dietary supplements as an additional source of folic acid. Bromat Chem Toksykol. 2012; 45(2): 152-158 (in Polish).

20. Sicińska E, Jeruszka-Bielak M, Masalska K, Wronowski S. Food fortified with vitamins on the Warsaw market. Rocz Panstw Zakl Hig. 2013; 64(4): 293-298.

21. Sicińska E, Bojarska K. Intakes of folic acid from dietary supplements and fortified products in students. Rocz Panstw Zakl Hig. 2013; 64(1): 55-59.

22. Tlałka E, Zadarko-Domaradzka M, Sobolewska M. Knowledge and attitude of women towards the diet supplementation with folic acid against the background of country-wide Program of Prevention of Neural Tube Defects. Prz Med. Uniw Rzesz Inst Lekow. 2008; 2: 161-165 (in Polish).

23. Ehmke vel Emczyńska E, Kunachowicz H. Questionnaire research among women of childbearing age concerning preliminary prevention of neutral tube defects. Hygeia Public Health 2011; 46(1): 47-50 (in Polish).

24. Bagłaj M, Wojtyłko A. Folic acid supplementation as prophylaxis of neural tube defect in the Lower Silesia region: fact or myth? Med Wieku Rozwoj. 2011; 15(4): 501-506 (in Polish).

25. Ministerstwo Zdrowia: 2009. Program kompleksowej diagnostyki i terapii wewnątrzmacicznej w profilaktyce następstw i powikłań wad rozwojowych i chorób płodu - jako element poprawy stanu zdrowia płodów i noworodków na lata 2009-2013. (Ministry of Health: 2009-2013 National plan for the diagnosis and treatment of NTDs). http://www.mz.gov.pl/wwwfiles/ma_struktura/docs/zal_ programwm_26052009.pdf (access: 2013.12.16) (in Polish). 